ARTIKEL PENELITIAN

\title{
PENGARUH TIMBAL ASETAT TERHADAP AKTIVITAS ENZIM KATALASE HATI TIKUS PUTIH JANTAN
}

\author{
Asterina, Endrinaldi \\ Bagian kimia Fakultas Kedokteran Universitas Andalas \\ email : endrinaldi29@yahoo.co.id
}

\begin{abstract}
Abstrak
Timbal $(\mathrm{Pb})$ dapat ditemukan di berbagai media lingkungan seperti udara, air, debu dan tanah. Logam $\mathrm{Pb}$ atau bentuk persenyawaannya berasal dari pembakaran bahan bakar kendaraan bermotor, emisi industri dan dari penggunaan cat bangunan yang mengandung $\mathrm{Pb}$. Toksisitas $\mathrm{Pb}$ menghambat sebahagian besar enzim yang terlibat dalam biosintesis heme dan merusak sel hati

Tujuan studi ini adalah untuk melihat pengaruh timbal $(\mathrm{Pb})$ terhadap aktivitas enzim katalase hati tikus puth jantan. Desain penelitian ini adalah eksperimental menggunakan 25 ekor tikus putih jantan yang dibagi menjadi lima kelompok, yaitu kelompok kontrol, dan kelompok perlakuan dengan pemberian $\mathrm{Pb}$ asetat dengan dosis konsentrasi $5 \mathrm{mg}, 10 \mathrm{mg}, 20 \mathrm{mg}$, dan $40 \mathrm{mg} / \mathrm{kg}$ BB selama 26 hari.

Hasil penelitian menunjukkan terjadinya penurunan rerata aktivitas katalase hati dan serum secara bermakna ( $\mathrm{p}<0,05)$, setelah pemberian $\mathrm{Pb}$ asetat selama 26 hari. Penurunan aktivitas katalase hati dan serum tikus secara bermakna $(\mathrm{p}<0,05)$ terjadi antara kelompok kontrol dibandingkan dengan kelompok tikus yang diberi dosis 40 $\mathrm{mg} / \mathrm{kg} \mathrm{BB}$.

Kesimpulan yang dapat diambil dari studi ini ialah bahwa pemberian $\mathrm{Pb}$ asetat dapat menurunkan aktivitas katalase hati dan juga mempengaruhi aktivitas katalase serum tikus.
\end{abstract}

Kata kunci : Pb asetat, katalase

\section{Abstract}

Lead $(\mathrm{Pb})$ can be found in various environmental media such as air, water, dust and dirt. $\mathrm{Pb}$ in the form of compounds derived from burning motor vehicle fuel, industrial emissions and from the use of paints containing $\mathrm{Pb}$ buildings. $\mathrm{Pb}$ toxicity partly inhibit the enzymes involved in the biosynthesis of heme and damage the liver cells.

The purpose of this study was to observe the effect of lead $(\mathrm{Pb})$ on the enzyme activity of rat liver catalase white male. Experimental research design was used 25 white male rats were divided into five groups, namely the control group and the 
group treated with the administration of $\mathrm{Pb}$ acetate at a dose concentration of $5 \mathrm{mg}$, $10 \mathrm{mg}, 20 \mathrm{mg}$, and $40 \mathrm{mg} / \mathrm{kg}$ body weight for 26 days.

The results showed an average decrease in liver catalase activity, after administration of $\mathrm{Pb}$ acetate for 26 days were significantly $(\mathrm{p}<0.05)$. Decrease in catalase activity of rat liver and serum were significantly $(\mathrm{p}<0.05)$ occurred between the control group compared with the group of mice given a dose of $40 \mathrm{mg} / \mathrm{kg}$.

The conclusion from this study is that the administration of $\mathrm{Pb}$ acetate can decrease the liver catalase activity and also affects the activity of serum catalase mice.

Key word : Pb Acetate, Catalase 


\section{PENDAHULUAN}

Timbal $(\mathrm{Pb})$ dapat ditemukan di berbagai media lingkungan seperti udara, air, debu dan tanah. Logam $\mathrm{Pb}$ atau bentuk persenyawaannya berasal dari pembakaran bahan bakar kendaraan bermotor, emisi industri dan dari penggunaan cat bangunan yang mengandung $\mathrm{Pb}$. Timbal $(\mathrm{Pb})$ di alam terdapat dalam dua bentuk yaitu gas dan partikel. $\mathrm{Pb}$ yang terbanyak di udara adalah $\mathrm{Pb}$ organik dan terutama berasal dari pembakaran tetra ethyl lead (TEL) dan tetra methyl lead (TEMEL) yang terdapat dalam bahan bakar kendaraan bermotor. Selain sumber-sumber di atas, logam berat ini juga terdapat pada gelas berwarna, keramik, pipa, pelapis kaleng tempat makanan, beberapa obat tradisional dan kosmetik. ${ }^{(1)}$ Pakar lingkungan sependapat bahwa $\mathrm{Pb}$ merupakan kontaminan terbesar dari seluruh debu logam di udara. ${ }^{(2)}$

Pencemaran timbal

$(\mathrm{Pb}) \quad \mathrm{di}$

lingkungan merupakan hasil pembakaran $\mathrm{Pb}$-alkil sebagai zat adiktif pada bahan bakar kendaraan bermotor merupakan bagian terbesar dari seluruh emisi $\mathrm{Pb}$ ke atmosfir berdasarkan estimasi sekitar $80 \%-90 \% \mathrm{~Pb}$ di udara ambien berasal dari pembakaran bensin. Kandungan $\mathrm{Pb}$ tidak sama antara satu tempat dengan tempat lainnya karena tergantung pada kepadatan kendaraan bermotor dan efisiensi upaya untuk mereduksi kandungan $\mathrm{Pb}$ pada bensin. ${ }^{(3)}$

Tetra ethyl lead (TEL) yang banyak pada bahan bakar terutama bensin, diketahui bisa menjadi racun yang merusak sistem pernapasan, sistem saraf, serta meracuni darah. Dari catatan Bank Dunia, terlihat bahwa dampak pencemaran udara oleh timbal di Indonesia telah menimbulkan 350 kasus penyakit jantung, 62.000 kasus tekanan darah tinggi, serta angka kematian 340 orang per tahunnya. ${ }^{(4)}$

$\mathrm{Pb}$ yang diabsorpsi diangkut oleh darah ke organ-organ tubuh sebanyak $95 \%, \mathrm{~Pb}$ dalam darah diikat oleh eritrosit. Sebagian $\mathrm{Pb}$ plasma dalam bentuk yang dapat berdifusi dan diperkirakan dalam keseimbangan dengan pool $\mathrm{Pb}$ tubuh lainnya yang dibagi menjadi dua yaitu ke jaringan lunak (hati, ginjal, sumsum tulang, sistem saraf) dan ke jaringan keras (tulang, gigi, kuku, rambut). ${ }^{(4)}$

Efek hematoksisitas $\mathrm{Pb}$ adalah menghambat sebahagian besar enzim yang terlibat dalam biosintesis heme. Diantara enzim yang terlibat dalam biosintesis heme yang dihambat $\mathrm{Pb}$ adalah enzim $\delta$-ALAD dan fero-kelatase. (5)

Penelitian tentang efek $\mathrm{Pb}$ terhadap aktivitas enzim $\delta$-ALAD terhadap hewan percobaan telah banyak dilakukan. Pemberian $\mathrm{Pb}$ selama 14 hari pada tikus menyebabkan penurunan aktivitas enzim $\delta$-ALAD secara signifikan dibandingkan dengan kontrol. ${ }^{(6)}$

Inhibisi aktivitas enzim $\delta$-ALAD dan ferokelatase oleh $\mathrm{Pb}$ menyebabkan penurunan biosintesis heme. Heme yang disamping berperan untuk biosintesis hemoglobin, juga berperanan penting untuk biosintesis enzim katalase yang dibutuhkan untuk menguraikan $\mathrm{H}_{2} \mathrm{O}_{2}$ (ROS, Reactive Oxygen Species) yang bersifat oksidan di dalam tubuh. ${ }^{(7)}$

Penelitian ini bertujuan untuk mengetahui pengaruh Timbal $(\mathrm{Pb})$ terhadap Aktivitas Enzim Katalase hati dan darah (serum) pada tikus. Pada penelitian ini diukur aktivitas enzim katalase hati dan serum tikus yang diberi Timbal $(\mathrm{Pb})$ dan yang tidak diberi Timbal (kontrol). 
Metode Penelitian

Penelitian ini merupakan penelitian eksperimental murni. Penelitian ini menggunakan 25 ekor tikus putih jantan yang dibagi 5 kelompok dengan masingmasing kelompok 5 ekor tikus. Kelompok tersebut antara lain $\mathrm{K}=$ kelompok kontrol (tikus tanpa diberi timbal), P1 = kelompok tikus yang diberi $\mathrm{Pb}$ asetat dengan dosis $5 \mathrm{mg} / \mathrm{kg} \mathrm{BB}, \quad \mathrm{P} 2=$ kelompok tikus yang diberi $\mathrm{Pb}$ asetat dengan dosis $10 \mathrm{mg} / \mathrm{kg} \quad \mathrm{BB}, \quad \mathrm{P} 3=$ kelompok tikus yang diberi $\mathrm{Pb}$ asetat dengan dosis $20 \mathrm{mg} / \mathrm{kg} \mathrm{BB}$, dan $\mathrm{P} 4=$ kelompok tikus yang diberi $\mathrm{Pb}$ asetat dengan dosis $40 \mathrm{mg} / \mathrm{kg} \mathrm{BB}$. Setelah 4 minggu, perlakuan dihentikan. Satu hari setelah perlakuan dihentikan, dibunuh secara dislokasi leher, kemudian dilakukan pengambilan darah dan hati yang dipersiapkan untuk pengukuran aktivitas enzim katalase hati dan serum.

\section{Hewan percobaan}

Hewan coba yang digunakan adalah tikus putih (Rattus norvegicus) jantan berumur dua sampai tiga bulan dengan berat badan antara $200-250$ gram.

\section{Perlakuan hewan coba}

Tikus yang digunakan untuk penelitian ini sebanyak 5 ekor, tikus ini diaklimatisasi dalam kondisi laboratorium selama satu minggu dengan diberi makanan dan minuman yang cukup.

Perlakuan diberikan sesuai dengan kelompoknya. Sebelum perlakuan, lebih dulu dilakukan penimbangan berat badan tikus. Bahan uji diberikan secara oral dengan menggunakan sonde yaitu alat suntik dengan jarum yang ujungnya ditumpulkan. Sonde dimasukkan dengan hati-hati, kira-kira mencapai lambung. $\mathrm{Pb}$ asetat diberikan setiap hari selama 26 hari. Selama perlakuan tikus diberi makanan standar dan air minum ad libitum.

\section{Penetapan Kadar Enzim Katalase}

a. Persiapan sampel

Satu gram hati tikus dicuci dengan $\mathrm{NaCl} \quad 0,9 \%$ dingin, hati tikus dihomogenasi dan tambahkan $1 \mathrm{ml}$ Triton X-100 1\% dan $\mathrm{NaCl}$ 0,9\% sampai $10 \mathrm{ml}$, setrifus. Supernatan diambil $1 \mathrm{ml}$ untuk uji aktivitas katalase

b. Uji aktivitas

1. Masukkan 800 mikromol $(0,0008$ mol) $\mathrm{H}_{2} \mathrm{O}_{2}$ ke dalam tabung. Ini sama dengan $4 \mathrm{ml}$ larutan $\mathrm{H}_{2} \mathrm{O}_{2}$ $0,2 \mathrm{M}$.

2. Tambahkan $5 \mathrm{ml}$ buffer Phospat.

3. Tambahkan $1 \mathrm{ml}$ homogenat dan inkubasi satu menit.

4. Ambil $1 \mathrm{ml}$ dari hasil reaksi ini, dan tambahkan ke dalam $2 \mathrm{ml}$ dichromate/asetat glacial. Dengan tabung yang berbeda ulangi prosedur ini dengan interval 60 detik.

5. Panaskan tabung selama 10 menit pada air mendidih untuk menghilangkan presipitat biru dan menghasilkan larutan hijau.

6. Ukur absorban pada panjang gelombang $570 \mathrm{~nm}$.

7. Gunakan kurva standar untuk menentukan berapa banyak $\mathrm{H}_{2} \mathrm{O}$ 2 yang tersisa di dalam serum saat reaksi dihentikan oleh asam asetat.

8. Setelah didapatkan jumlah $\mathrm{H}_{2} \mathrm{O}_{2}$ (mikromol) yang tersisa, maka untuk mendapatkan berapa banyak $\mathrm{H}_{2} \mathrm{O}_{2}$ yang telah dihancurkan oleh katalase adalah: $\mathrm{H}_{2} \mathrm{O}_{2}$ 
yang direaksikan (800 mikromol)$\mathrm{H}_{2} \mathrm{O}_{2}$ yang tersisa.

9. Aktivitas katalase (unit $/ \mathrm{mg})=$

${ }_{2} \mathrm{O}_{2}$ yang dihancurkan katalase/menit

Kadar Protein serum $(\mathrm{mg} / \mathrm{ml})$

\section{Penentuan Kadar Protein}

1. Masukkan $0,005 \mathrm{ml}$ serum ke dalam tabung reaksi.

2. Tambahkan $3 \mathrm{ml}$ larutan Kingsley dan homogenkan dengan perlahan dan dibiarkan pada suhu kamar selama 15 menit.

3. Setelah 15 menit, baca absorbannya pada panjang gelombang $536 \mathrm{~nm}$.

4. Lakukan juga prosedur ini pada serum standar yang telah diketahui kadar proteinnya sebagai perbandingan.
5. Absorban yang didapat dimasukkan ke dalam rumus :

$\begin{aligned} & \text { Kadar protein sampel } \\ & \text { standar }(\mathrm{mg} / \mathrm{ml})\end{aligned}=\frac{\text { A sampel }}{\text { A standar }} \times$ Kadar protein

\section{Analisis Statistik}

Data diolah dengan menggunakan Anova satu jalan dengan derajat kepercayaan 95\%. Jika terdapat perbedaan bermakna antara kelima kelompok perlakuan $(\mathrm{p}<0,05)$, maka dilanjutkan dengan Post Hoc Test.

\section{Hasil}

Hasil yang diperoleh pada pengujian aktivitas katalase hati dan serum adalah sebagai berikut :

Tabel 1. Rerata aktivitas katalase hati (unit/mg) tikus pada ke lima kelompok

\begin{tabular}{cccc}
\hline $\begin{array}{c}\text { Kelompok } \\
(\mathrm{N}=5)\end{array}$ & Rerata & SD & $\mathrm{P}$ \\
\hline $\mathrm{K}$ & 58,658 & 8,880 & 0,004 \\
$\mathrm{P} 1$ & 58,584 & 6,360 & \\
$\mathrm{P} 2$ & 55,542 & 2,753 & \\
P3 & 54,846 & 2,374 & \\
$\mathrm{P} 4$ & 42,162 & 8,905 & \\
\hline
\end{tabular}

Tabel 1 memperlihatkan adanya penurunan rerata aktivitas katalase hati pada kelompok perlakuan. Berdasarkan uji Anova pada ke lima kelompok tikus menunjukkan adanya perbedaan yang bermakna $(\mathrm{p}<0,05)$ antar kelompok tikus $(\mathrm{K}$, P1, P2, P3 dan P4). 
Tabel 2. Tingkat Kemaknaan Hasil Uji Tukey HSD terhadap Aktivitas Katalase Hati Tikus

\begin{tabular}{cccc}
\hline Kelompok & Kelompok & $\begin{array}{c}\text { Perbedaan } \\
\text { rata-rata }\end{array}$ & P \\
\hline K & P1 & 0,07400 & 1,000 \\
& P2 & 3,11600 & 0,940 \\
& P3 & 3,81200 & 0,883 \\
& P4 & $16,49600^{*}$ & 0,006 \\
P1 & P2 & 3,04200 & 0,945 \\
& P3 & 3,73800 & 0,890 \\
& P4 & $16,42200^{*}$ & 0,006 \\
P2 & P3 & 0,69600 & 1,000 \\
& P4 & $13,38000^{*}$ & 0,029 \\
P3 & P4 & $12,68400^{*}$ & 0,042 \\
\hline
\end{tabular}

*. terdapat perbedaan bermakna pada $\mathrm{p}<0,05$

Tabel 2 menunjukan penurunan rerata aktivitas katalase hati tikus secara bermakna antara kelompok K (kontrol) dengan kelompok P4, kelompok P1 dengan kelompok P4, kelompok P2 dengan kelompok P4, kelompok P3 dengan kelompok P4.

Tabel 3. Rerata aktivitas katalase serum (unit/mg) tikus pada ke lima kelompok

\begin{tabular}{cccc}
\hline $\begin{array}{c}\text { Kelompok } \\
(\mathbf{N}=\mathbf{5})\end{array}$ & Rerata & SD & P \\
\hline K & & & \\
P1 & 9,792 & 0,477 & 0,003 \\
P2 & 9,946 & 0,173 & \\
P3 & 9,956 & 0,198 & \\
P4 & 9,668 & 0,357 & \\
\hline
\end{tabular}


Tabel 3 memperlihatkan adanya perbedaan rerata aktivitas katalase serum tikus pada kelompok perlakuan. Berdasarkan uji Anova pada ke lima kelompok tikus menunjukkan adanya perbedaan yang bermakna $(\mathrm{p}<0,05)$ antar kelompok tikus $(\mathrm{K}$, P1, P2, P3 dan P4).

Tabel 4. Tingkat Kemaknaan Hasil Uji Tukey HSD terhadap Aktivitas Katalase Serum Tikus

\begin{tabular}{cclc}
\hline Kelompok & Kelompok & $\begin{array}{l}\text { Perbedaan } \\
\text { rata-rata }\end{array}$ & p \\
\hline $\mathrm{K}$ & $\mathrm{P} 1$ & $-0,15400$ & 0,936 \\
& $\mathrm{P} 2$ & $-0,16400$ & 0,921 \\
& $\mathrm{P} 3$ & 0,12400 & 0,970 \\
& $\mathrm{P} 4$ & $0,65800^{*}$ & 0,026 \\
$\mathrm{P} 1$ & $\mathrm{P} 2$ & 0,01000 & 1,000 \\
& $\mathrm{P} 3$ & 0,27800 & 0,639 \\
& $\mathrm{P} 4$ & $0,81200^{*}$ & 0,005 \\
$\mathrm{P} 2$ & $\mathrm{P} 3$ & 0,28800 & 0,609 \\
& $\mathrm{P} 4$ & $0,82200^{*}$ & 0,004 \\
$\mathrm{P} 3$ & $\mathrm{P} 4$ & 0,53400 & 0,094 \\
\hline
\end{tabular}

*. terdapat perbedaan bermakna pada $\mathrm{p}<$ 0,05

Tabel 4 menunjukan perbedaan aktivitas katalase serum tikus secara bermakna antara kelompok K (kontrol) dengan kelompok P4, kelompok P1 dengan kelompok P4 dan kelompok P2 dengan kelompok P4

\section{Pembahasan}

Penelitian yang dilakukan terhadap 25 ekor tikus putih jantan dibagi menjadi lima kelompok, yaitu kelompok kontrol (K), kelompok perlakuan yang 
diberi $\mathrm{Pb}$ asetat konsentrasi $5 \mathrm{mg}, 10 \mathrm{mg}$, $20 \mathrm{mg}$, dan $40 \mathrm{mg} / \mathrm{kg}$ BB selama 26 hari.

Berdasarkan tabel 1 terlihat bahwa rerata aktivitas katalase hati tikus kelompok kontrol lebih tinggi daripada kelompok perlakuan, dan menunjukan juga bahwa aktivitas katalase hati menurun sejalan dengan peningkatan konsentrasi $\mathrm{Pb}$ yang diberikan dalam rentang tertentu. Terjadi penurunan aktivitas katalase hati ini disebabkan karena timbal $(\mathrm{Pb})$ dapat menghambat biosintesis heme yang diperlukan untuk membentuk enzim katalase dengan cara menurunkan/menghambat aktivitas enzim $\delta$-ALAD yang berperan dalam biosintesis heme tersebut. ${ }^{(5)}$ Berarti secara tidak langsung $\mathrm{Pb}$ dapat menghambat biosintesis enzim katalase.

Berdasarkan tabel 2 terlihat penurunan aktivitas katalase hati secara bermakna $(p<0,05)$ terjadi antara kelompok kontrol terhadap kelompok perlakuan yang diberi konsentrasi $\mathrm{Pb}$ asetat $40 \mathrm{mg} / \mathrm{kg} \mathrm{BB}$. Ini menunjukan bahwa kelompok yang diberi konsentrasi $40 \mathrm{mg} / \mathrm{kg}$ BB berpengaruh terhadap penurunan aktivitas katalase hati. Sedangkan kelompok yang diberi $\mathrm{Pb}$ asetat konsentrasi $5 \mathrm{mg}, 10 \mathrm{mg}$, dan 20 $\mathrm{mg} / \mathrm{kg} \quad \mathrm{BB}$ berpengaruh terhadap penurunan aktivitas katalase hati secara tidak bermakna. Berarti pemberian $\mathrm{Pb}$ asetat konsentrasi $5 \mathrm{mg}, 10 \mathrm{mg}$, dan 20 $\mathrm{mg} / \mathrm{kg}$ BB merupakan konsentrasi yang belum efektif menghambat biosintesis katalase.

Berdasarkan analisis Post Hoc Test (tabel 4) menunjukan bahwa rerata aktivitas katalase serum tikus memperlihatkan peningkatan aktivitas secara tidak bermakna pada pemberian $\mathrm{Pb}$ asetat konsentrasi rendah (5 $\mathrm{mg}$ dan 10 $\mathrm{mg} / \mathrm{kg}$ BB) dan aktivitas katalase menurun secara tidak bermakna pada pemberian konsentrasi $20 \mathrm{mg} / \mathrm{kg}$ BB dan menurun secara bermakna pada 40 $\mathrm{mg} / \mathrm{kg}$ BB. Hal ini disebabkan karena $\mathrm{Pb}$ dapat menyebabkan kerusakan sel hati dan menghambat/menurunkan biosintesis katalase di hati. Meningkatnya jumlah enzim katalase di darah (serum) pada pemberian $\mathrm{Pb}$ asetat konsentarsi rendah (5 mg dan $10 \mathrm{mg} / \mathrm{kg}$ BB) disebabkan karena pada konsentrasi ini, $\mathrm{Pb}$ asetat telah dapat merusak sel hati, ${ }^{(8)}$ maka katalase di dalam sel akan berdifusi ke dalam darah, tetapi belum efektif menghambat biosintesis katalase, sehingga katalase meningkat jumlahnya di dalam darah. Sebaliknya jumlah enzim katalase akan menurun di darah (serum) pada pemberian $\mathrm{Pb}$ asetat dengan konsentrasi $20 \mathrm{mg}$ dan $40 \mathrm{mg} / \mathrm{kg}$ BB (tabel 4), hal ini disebabkan karena pada konsentrasi $\mathrm{Pb}$ asetat ini disamping menyebabkan terjadinya kerusakan sel yang hebat juga terjadi penghambatan biosintesis katalase di hati secara bermakna (tabel 1), sehingga jumlah katalase di darah (serum) menurun setelah pemberian $\mathrm{Pb}$ asetat konsentrasi $10 \mathrm{mg} / \mathrm{kg} \mathrm{BB}$.

\section{Kesimpulan}

Dari hasil penelitian tentang pengaruh timbal $(\mathrm{Pb})$ terhadap aktivitas enzim katalase hati tikus putih jantan yang telah dilakukan di Laboratorium Fakultas Farmasi dan Laboratorium Biokimia Fakultas Kedokteran Universitas Andalas diperoleh kesimpulan sebagai berikut :

1. Terdapat pengaruh pemberian $\mathrm{Pb}$ asetat terhadap penurunan aktivitas enzim katalase hati tikus antara kelompok kontrol dengan kelompok perlakuan.

2. Tidak terdapat pengaruh penurunan secara bermakna aktivitas enzim 
katalase hati pada pemberian $\mathrm{Pb}$ asetat antara kelompok kontrol dengan kelompok yang diberi dosis $5 \mathrm{mg}, 10 \mathrm{mg}$ dan $20 \mathrm{mg}$ per $\mathrm{kg}$ BB.

3. Terdapat pengaruh penurunan secara bermakna aktivitas katalase hati tikus pada pemberian $\mathrm{Pb}$ asetat antara kelompok kontrol dengan kelompok yang diberi dosis $40 \mathrm{mg}$ per $\mathrm{kg} \mathrm{BB}$.

4. Terdapat pengaruh pemberian $\mathrm{Pb}$ asetat terhadap aktivitas enzim katalase serum tikus antara kelompok kontrol dengan kelompok perlakuan.

5. Terdapat pengaruh penurunan secara bermakna aktivitas katalase serum tikus pada pemberian $\mathrm{Pb}$ asetat antara kelompok kontrol dengan kelompok yang diberi dosis $40 \mathrm{mg}$ per $\mathrm{kg} \mathrm{BB}$.

\section{Saran}

Telah diketahui dengan baik bahwa hati memainkan peranan yang penting pada proses detoksifikasi dan ketika ada zat yang bersifat toksik yaitu timbal $(\mathrm{Pb})$ yang dapat mempengaruhi aktvitas enzim katalase. Untuk itu disarankan penelitian lanjutan mengenai studi tentang zat kimia (obat) yang dapat meredam pengaruh $\mathrm{Pb}$ terhadap penurunan aktivitas enzim katalase

\section{KEPUSTAKAAN}

1. Tong, S., Von-schimding, Y.E., Prapamontol, T. 2000. Environmental lead exposure: a public health problem of global dimensions. Bull WHO 78: 106877.
2. Winarno, F.G. 1993. Pangan, Gizi, Teknologi dan Konsumen. Jakarta. Penerbit PT Gramedia Pustaka Utama.

3. Noery A. 2006. Perbandingan Kadar $\mathrm{Pb}$, $\mathrm{Hb}$, Fungsi Hati, Fungsi Ginjal pada Karyawan BBTKL dan PPM Surabaya Bagian Sampling dan Non Sampling. Jurnal Kesehatan Lingkungan. Vol. 2 No. 2. Januari 2006

4. Heryanto P. 1994. Pencemaran Dan Toksikologi Logam Berat. : 20-30.

5. Goldstein, B.D. \& Kipen, H.M. 1994. Hematologic Desolder in Levy and Wagmen. Occuputional Health Recognizing and Preventing Wold-Realted Deseases $3^{r d}$.

6. Hasan, M.Z. and Seth, T.D. 1981. Effect of lead and Zinc Administration of Liver, Kidney and Brain Levels of Copper, Lead, Mangan and Zinc on Erithrocyte ALA-D Activity In Rats. Toxicology, 353-8.

7. Murray RK. 2003. Biokimia Harper. Alih bahasa, Hartono, A., Ed-25, Jakarta: EGC,hlm 270-82.

8. Sipos, P., Szentmihalyi, K., Feher, E., Abaza, M., Szilagyi, M., Blazovics, A. 2003. Some effects of lead contamination on liver and gallbladder bile. Acta Biologica Szegediensis. 47(1-4): 139-42. 
